\title{
Evaluation of an odor repellent for protecting crops from wild boar damage
}

\author{
Adrian Schlageter · Daniel Haag-Wackernagel
}

Received: 5 December 2011/Accepted: 29 January 2012/Published online: 12 February 2012

(C) Springer-Verlag 2012

\begin{abstract}
Wild boar populations have dramatically increased in the past decades and the species has spread all over Europe. As the wild boar expanded its activity range into agricultural land, conflicts with humans have intensified. Today, the damage caused by wild boar amounts to millions of dollars every year. In Switzerland, farmers usually protect fields with electric fences, which have proven to be effective in preventing damage, but are also expensive. Alternatively, various cheaper deterrents and repellents are commercially available. However, most of them lack scientific proof of efficacy. In the present study, we investigated the effectiveness of the odor repellent "Wildschwein-Stopp ${ }^{\circledR}$ " against wild boar. We conducted field experiments with free-ranging wild boars at baited luring sites, which were placed in three different regions of the Canton Basel-Land, Northwest Switzerland. The odor repellent was not able to prevent the wild boars from entering our luring sites. We recorded a minimal and nonsignificant deterrent effect of $0.4 \%$. Our results lead to the conclusion that the repellent is ineffective and, therefore, not recommendable for crop protection. On the basis of the present study we generally doubt fear-inducing repellents to be effective against wild boars and feral pigs. Our findings may indicate seasonal variation in wild boar activity outside forests since the probability of wild boar visits at the luring sites differed according to the season. The visits at the luring sites peaked in spring and fall which
\end{abstract}

Communicated by M. Traugott.

A. Schlageter $(\bowtie) \cdot D$. Haag-Wackernagel

Department of Biomedicine, Institute of Anatomy, University of

Basel, Pestalozzistrasse 20, 4056 Basel, Switzerland

e-mail: adrian.schlageter@unibas.ch coincides with the occurrence of damage to agricultural land.

Keywords Crop protection - Damage prevention · Human-wildlife conflict . Odor repellent .

Sus scrofa . Wildschwein-Stopp

\section{Introduction}

The wild boar (Sus scrofa) is the fifth largest ungulate species in Europe and has an area-wide spread over the entire European continent (Briedermann 1990; Macdonald 2001). The species has naturally colonized new areas over the past decades. The spread and increase in population size of the highly opportunistic and omnivorous species, resulting in higher boar activity in farmland, have intensified conflicts with humans (Schley and Roper 2003). Wild boars can cause considerable damage to crops and grassland. In many European countries, governmental compensations for crop damage amount to millions of Euros every year (Mazzoni della Stella et al. 1995; Vassant 1997; Calenge et al. 2004). Since about 1970, the spread and size of populations have increased in Switzerland, which is manifested by continuously increasing wild boar bags. Accordingly, crop damage increased dramatically and became unacceptable to farmers and game authorities because of the financial implications relating to increasing compensation payments for wild boar damage to crops and grassland (Geisser 1998).

This is also true for the Canton Basel-Land, a region in Northwestern Switzerland, which has to cope with high wild boar densities (yearly published hunting data of the Canton Basel-Land (www.baselland.ch/main_statistik-htm. 281141.0.html). Following the spread of the species over 
Switzerland, the population started to grow in the early 80s, causing increasing problems in agriculture.

Three methods dominate among the attempts to reduce wild boar damage that are recommended in many scientific and popular articles (Briedermann 1990; Breton 1994; Mazzoni della Stella et al. 1995; Vassant 1997; Geisser 1998). First, wild boars are hunted intensively to keep population densities low. Second, farmers put up fences and other deterrent systems to prevent wild boars from entering the fields. Third, hunters offer supplemental food in the forest to keep the wild boars off the farmland. The effectiveness of supplemental feeding in terms of damage reduction is highly controversial and seems to depend on several aspects. While some studies provide evidence for the success of the method in reducing wild boar damage to agricultural crops (Vassant and Breton 1986; Meynhardt 1991; Vassant et al. 1992; Vassant 1994a, b; Calenge et al. 2004), others showed no, or even negative effects (Hahn and Eisfeld 1998; Geisser and Reyer 2004; Cellina 2008). Additional food enhances survival under poor environmental conditions and accelerates the onset of reproduction, which both can lead to population growth (Andrzejewski and Jezierski 1978; Briedermann 1990; Bieber and Ruf 2005). In those studies that reported successful damage reduction by means of supplemental feeding, food was supplied inside the forest at a distance of at least $1 \mathrm{~km}$ from the edge of the forest, the food supplied was spread out over large areas and was only provided during the critical period. These criteria are hard to be met in Switzerland with its highly fragmented landscape and patchy forest distribution. In the Canton Basel-Land, supplemental feeding is mainly practiced to bait wild boars for easier shooting. Hunting seems to clearly reduce wild boar damage (Geisser and Reyer 2004). Nevertheless, wild boar reproductive rates can increase up to $200 \%$ under ideal conditions (Briedermann 1990). Thus, populations are able to compensate the abatement inflicted by hunting within 1 year. Mild winters, warm springs, and the abundant crop of common acorn (Quercus robur) and common beech (Fagus sylvatica) during recent winters provided ideal conditions for the wild boars to thrive over the past years (Geisser and Reyer 2005). Hence, protection of the fields will remain essential in the future. Farmers preferably protect vulnerable fields with electrical fences, which have been proven to be an effective means to prevent access to crops for wild boars in the past (Boisaubert et al. 1983; Vassant and Boisaubert 1984). However, electrical fences require regular surveillance to assure maintenance of both fences and batteries, which is costly in terms of time. In addition, electrical fences are expensive and the government does not provide financial support. In the Canton Basel-Land, reimbursement for fencing costs repeatedly exceeded compensation payments in the past years and was therefore disestablished in 2008. The wildlife damage compensation fund is directly fed from the hunting licenses and the lease fees for hunting grounds. This commitment by the hunters provides an incentive for appropriate and intensive hunting.

However, farmers and authorities are highly interested in efficient alternatives to the expensive and labor-intensive electrical fence. Various deterrents are available today that claim to be effective in deterring wild boars. Methods based on acoustic, gustatory, and optic deterrence have not yielded satisfactory long-term results (Vassant and Boisaubert 1984; Vassant 1994a; Schlageter and Haag-Wackernagel 2011). These methods include radios, PIR-activated horns, gas cannons, chemical treatment of corn seeds with several repellents, and solar-powered LED-blinkers.

At present, there is little or no data to support claims of efficacy for the majority of commercially available deterrent systems, which particularly applies to odor repellents. Information on successful deterrence of wild boars mainly derives from the manufacturers of the deterrent systems themselves. In Switzerland, odor repellents are predominantly used to reduce collisions with game animals on frequented rural roads. The most common repellent is a scent fence called "Duftzaun ${ }^{\circledR}$ ", a chemical repellent that imitates predator urines, which is mainly used to deter roe deer. Many popular articles support the effectiveness of this repellent. Game authorities from several cantons of Switzerland but also in many regions in Germany and Austria use the scent fence to reduce wildlife collisions. Lutz (1994), however, could show that this odor repellent was not effective, neither in provoking startle responses by target animals, nor in reducing accidents with cervids on a rural road.

Olfaction is known to be the most pronounced sense in wild boar, playing an important role in the biology of the species. Wild boars not only use olfaction for orientation and foraging but also for intra-specific social interactions and for avoidance of natural enemies including man (Meynhardt 1978). Günterschulze (1979) found that the olfactory epithelium of wild boar has the largest surface area and most olfactory receptor cells of all species investigated so far. Humans make use of the well-developed olfaction of wild boar and its domesticated descendants using them as truffle pigs, sniffer pigs or "bloodhounds" (Zeuner 1967; Altevogt 1972; Briedermann 1990).

Against this background, odor repellents might be a promising means for deterring wild boar from agricultural crops. A deterrent commercially available that particularly claims to deter wild boar is "Wildschwein-Stopp ${ }^{\circledR}$ ", a chemical repellent imitating a mixture of several predator odors. "Wildschwein-Stopp ${ }^{\circledR}$ " has been tested in only a few unpublished trials in the past which were conducted by hunters and farmers. These tests reasoned that the repellent was effective in deterring wild boar and protecting fields. 
Yet the positive reports are rather anecdotal and these studies did not meet scientific criteria. However, these field reports have attracted the interest of game authorities of the Canton Basel-Land. In the present study, we investigated the effectiveness of "Wildschwein-Stopp ${ }^{\circledR}$ " in field experiments with free-ranging wild boars.

\section{Materials and methods}

\section{Study area}

The present study was conducted in three municipal areas in the Canton Basel-Land, northwestern Switzerland. We performed field experiments between July 2007 and December 2008 at four different study sites in Sissach $\left(47^{\circ} 28^{\prime} 0.01^{\prime \prime} \mathrm{N}\right.$, $\left.7^{\circ} 49^{\prime} 0.01^{\prime \prime} \mathrm{E}\right)$, Rothenfluh $\left(47^{\circ} 27^{\prime} 43.98^{\prime \prime} \mathrm{N}, 7^{\circ} 54^{\prime} 58.03^{\prime \prime} \mathrm{E}\right)$, and Hofstetten $\left(47^{\circ} 28^{\prime} 39.98^{\prime \prime} \mathrm{N}, 7^{\circ} 30^{\prime} 55.04^{\prime \prime} \mathrm{E}\right)$. Two study sites were located in Rothenfluh (Rot1 and Rot2), one each in Sissach (Sis) and Hofstetten (Hof). These three municipal areas have been affected by repeated and severe wild boar damage in the recent past. The Canton Basel-Land is situated in northwestern Switzerland and covers an area of $518 \mathrm{~km}^{2}$, which ranges in elevation from 250 to $1,170 \mathrm{~m}$. The climate is continental with an average annual precipitation of $750-1,300 \mathrm{~mm}$, and average temperatures range from $2.1^{\circ} \mathrm{C}$ in January to $19.6^{\circ} \mathrm{C}$ in July. Forests cover $42 \%$ of the study area and are mostly used for the lumber industry. Agricultural land covers $41 \%$ of the area and consists mainly of pasture (50\%), cropland (40\%), and fruit- and winegrowing (10\%). The landscape is characterized by hilly topography, patchy forest distribution, and high structural diversity. Except for the Eurasian lynx (Lynx lynx), natural predators of the wild boar are absent in Northwestern Switzerland.

\section{Deterrent system}

The odor repellent spray "Wildschwein-Stopp ${ }^{\circledR}$ " from Hagopur Inc. is available in $500 \mathrm{ml}$ aerosol spray. It claims to particularly deter wild boars by an offensive smell that should reflect a mixture of several predator odors. According to the manufacturer, the odor was composed of isobutane $(30-60 \%)$, naphtha $(1-15 \%)$, propane $(1-10 \%)$, propane-2-ol (1-5\%), 3-methyl butyric acid (1-5\%), and non-hazardous additives. Hagopur Inc. also provides purpose built aluminum strips with felt depots on which the repellent can be sprayed. The manufacturer claims that these aluminum strips should have an additional deterrence effect by reflecting light and by making noise when moved by the wind. According to the instructions for use the repellent should be sprayed on the aluminum sheets, which are fixed on shrubs or posts at waist height in a spacing of $8-15 \mathrm{~m}$. It is advised to refresh the repellent every 2-4 weeks.

\section{Experimental design}

The odor repellent was investigated at baited luring sites set up in grassland near the forests. Allurement was performed providing an attractive food mixture composed of apple, maize, and protein-enriched food pellets. The luring sites were placed on frequently used wild boar trails, which we had previously spotted with the help of local hunters. Wild boars use these trails when leaving the forest to forage in agricultural land, or when crossing the open land to get from one forest to another. We placed study sites within the known wild boar trail area aiming to achieve a high chance of wild boars to be attracted by the lure food. A study site always consisted of two luring sites, one as a test site $(\mathrm{T})$ and one as a control site $(\mathrm{C}), 6 \times 6 \mathrm{~m}$ each. The test site was surrounded by the deterrent system and the control site remained without protection. Distance between the two luring sites was $90-115 \mathrm{~m}$ to prevent interference of $\mathrm{C}$ by the odor repellent installed at $\mathrm{T}$. We therefore also accounted for the topographic conditions, making intervisibility between $\mathrm{C}$ and $\mathrm{T}$ impossible, as well as for the common wind direction. Following the manufacturers' instructions, we sprayed the odor repellent on the felt depots of the purpose built aluminum sheets. The sheets were fixed on 8 posts at waist height spaced at intervals of $3 \mathrm{~m}$ around the luring sites, forming a $36-\mathrm{m}^{2}$ treatment area. Regardless of the manufacturers' advice to refresh the repellent every 2-4 weeks, we repeatedly treated the felt depots every week. Furthermore, we covered the aluminum strips with transparent plastic bags with a wide opening at the bottom side to protect the felt depots from precipitation but to allow for the optic, acoustic, and odor repellency.

We inspected the luring sites daily or at least every second day. At each inspection, any wild boar tracks were recorded. For this purpose we built a track-band consisting of a $50 \mathrm{~cm}$ broad and $10 \mathrm{~cm}$ deep ditch filled with soil and sand surrounding the bait. The track-band was regularly dampened to insure that visits by wild boars or other animals would leave a mark. Every time wild boars visited a luring site, $\mathrm{C}$ and $\mathrm{T}$ were switched by removing the deterrent system from $\mathrm{T}$ and installing it at former $\mathrm{C}$ and vice versa. In choosing this regime of constant alternation between the two luring sites we aimed at preventing the wild boars from habituating themselves to the experimental setup. Furthermore we were able to account for the possibility of biased visits at one of the two luring sites compared to the other. 
Statistical analysis

We assessed by logistic regression analysis the effect of the "Wildschwein-Stopp ${ }^{\circledR}$ " on the probability of wild boar visits at the luring sites. The binary indicator variable of a wild boar visit was the dependent variable and the two-level factor treatment ( $\mathrm{T}$ vs. $\mathrm{C}$ ) was the predictor of interest. We further controlled the influence of month, the duration of the experiment ( $n$ days), the study site and the interactions treatment $\times$ month, treatment $x$ duration, and treatment $\times$ site. We included the interactions to test whether there are differences in a potential effect of treatment between the months, the sites, or with ongoing duration of the experiments. The variable month was treated as a factor with 12 levels. To account for non-linear effects we also included the quadratic and cubic effect of duration. Starting with a model including all predictors, we gradually removed the non-significant interactions, the quadratic and cubic effects from the model, leaving the main effects within it. We used the Likelihood ratio test for model comparisons. The analyses were done using the $\mathrm{R}$ software for statistical computing.

In addition, we calculated a zero-inflated model to verify the $P$ values of the logistic regression model, because analysis of residuals indicated that there were too many zero values in our data (days on which neither $\mathrm{T}$ nor $\mathrm{C}$ were visited). The zero-inflated model consisted of two Bernoulli models with logistic link functions each. The first model described whether there were wild boars around which potentially could visit a luring site. Predictor in this model was the day of the year. The second model described the probability of a visit conditional on wild boars being around. In this model duration, the quadratic and cubic effect of duration, study site and treatment were predictors. We used Bayesian methods for model fitting. Parameters were estimated by running Markov chain Monte Carlo simulations using WinBUGS (Spiegelhalter et al. 2003). WinBUGS was accessed by $\mathrm{R}$ via $\mathrm{R}$-interface $\mathrm{R} 2 \mathrm{Win}$ BUGS (Sturtz et al. 2005). Markov chain Monte Carlo simulations produced a random sample from the posterior distribution of the model parameters. Therefore, we were able to directly calculate the effectiveness of the odor repellent in reducing the probability of wild boar visits.

\section{Results}

Table 1 gives an overview of the duration of experiments, number of inspections, and number of visits for each study site. Of a total of 453 inspections performed during the whole study period, we recorded 80 visits of wild boars at the study sites (17.7\%). In the majority of the cases both
$\mathrm{C}$ and $\mathrm{T}$ were visited during the same night $(n=76)$. Overall, we recorded successful surmounting of the deterrent system (visits at $\mathrm{T}$ ) by wild boars in 76 cases, whereas $\mathrm{C}$ was visited 80 times. Wild boars completely consumed the lure food in $92 \%$ of all visits.

The results of the logistic regression are given in Table 2. The odor repellent did not have a significant effect on wild boar visits at the luring sites. The interactions treatment $\times$ month, treatment $\times$ duration, and treatment $\times$ site did not have a significant influence on wild boar visits either. Only the month, the duration plus its quadratic- and cubic effect, and the site significantly influenced the probability of wild boar visits at the luring sites. Explanatory variables month and duration were slightly correlated $(r=0.3288, \mathrm{df}=451, P<0.001)$. We

Table 1 Duration of field experiments (days), number of inspections, and numbers of wild boar visits at the luring sites ( $\mathrm{C}$ control site, $\mathrm{T}$ test site, $\mathrm{C}+\mathrm{T}$ both sites visited together during the same night) for the study sites at Sissach (Sis), Rothenfluh (Rot1, Rot2), and Hofstetten (Hof), Canton Basel-Land, Switzerland in 2007/2008

\begin{tabular}{lrrrrr}
\hline Study site & Sis & Rot1 & Rot2 & Hof & Total \\
\hline Duration of experiment & 539 & 329 & 391 & 187 & 1446 \\
Inspections & 190 & 91 & 125 & 47 & 453 \\
Visits at C + T & 29 & 15 & 22 & 10 & 76 \\
Visits at C exclusively & 3 & 0 & 1 & 0 & 4 \\
Total & 32 & 15 & 23 & 10 & 80 \\
\hline
\end{tabular}

Table 2 Significance tests (likelihood ratio tests) of the logistic regression to predict whether a luring site is likely to be visited by wild boars, or not

\begin{tabular}{|c|c|c|c|c|}
\hline $\begin{array}{l}\text { Predictor } \\
\text { variables }\end{array}$ & df & LR & $P$ value & $P$ value of reduced model \\
\hline Treatment & 1 & 0.136 & 0.712 & \\
\hline Month & 11 & 35.165 & $<0.001$ & $\begin{array}{l}<0.001 \text { (model without } \\
\text { duration) }\end{array}$ \\
\hline Duration & 1 & 18.877 & $<0.001$ & $\begin{array}{l}<0.001 \text { (model without } \\
\text { month) }\end{array}$ \\
\hline Duration $^{2}$ & 1 & 15.843 & $<0.001$ & $\begin{array}{l}<0.001 \text { (model without } \\
\text { month) }\end{array}$ \\
\hline Duration $^{3}$ & 1 & 11.702 & $<0.001$ & $\begin{array}{l}<0.001 \text { (model without } \\
\text { month) }\end{array}$ \\
\hline Site & 3 & 10.600 & 0.014 & \\
\hline $\begin{array}{l}\text { Treatment } \times \\
\text { site }\end{array}$ & 3 & 0.096 & 0.992 & \\
\hline $\begin{array}{l}\text { Treatment } \times \\
\text { month }\end{array}$ & 11 & 0.065 & 0.996 & \\
\hline $\begin{array}{c}\text { Treatment } \times \\
\text { duration }\end{array}$ & 1 & 0.026 & 0.872 & \\
\hline
\end{tabular}

Predictors "month" and "duration" were correlated. We, therefore, calculated the influence of these variables in two separate models 


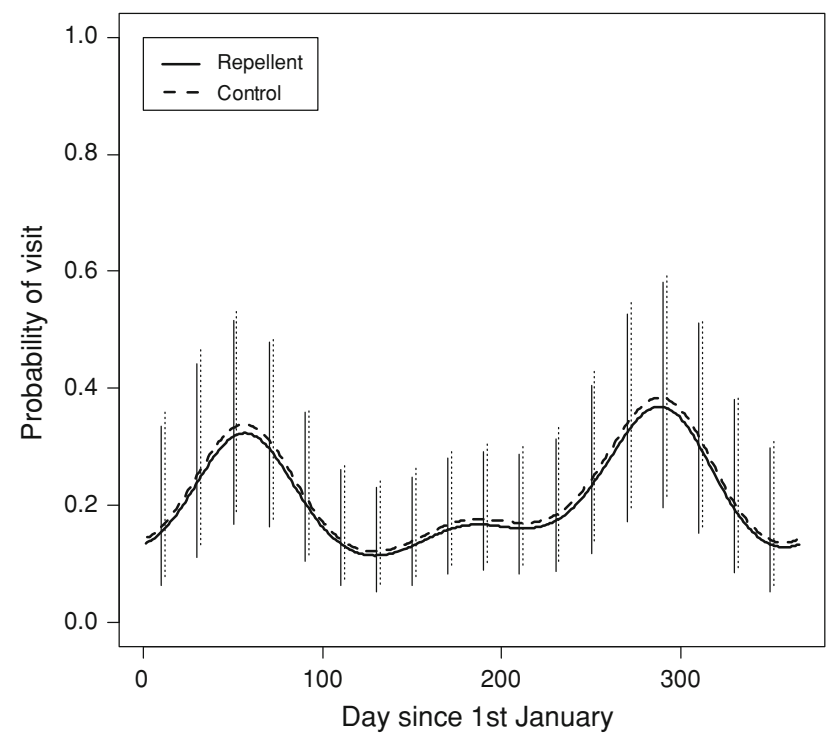

Fig. 1 Probability of wild boar visits at the luring sites as a function of the day of the year (including 95\% CI)

therefore calculated two logistic models, one where the month was corrected for the effect of duration and a model where the duration was corrected for the effect of the month. It appears that the effect of the duration was overlain by the differences between the months and a complete separation of the effect was not feasible due to the correlation between the duration and month. However, neither of the two models was significantly more explanatory than the other.

Figure 1 shows the outcome of the zero-inflated model, which confirms the result of the logistic regression. The probability of wild boar visits at $\mathrm{T}$ was 0.996 compared to C (95\% credible Interval: $0.779,1.215)$. Thus, the odor repellent reduced the probability of wild boar visits at the luring sites by $0.4 \%$. Figure 1 also demonstrates the seasonal variation in wild boar visits. The between-month difference of probability of wild boar visits was significant $\left(\mathrm{LR}_{11}=35.17, P<0.001\right)$. Maximum values for probability of visits was reached in March with $0.41-0.43$ (T-C), and in fall (Sep, Oct) with $0.31-0.32$, and $0.39-0.40$, respectively. Probability of wild boar visits was also significantly different between the four study sites $\left(\mathrm{LR}_{3}=10.6, P=0.014\right)$, which is demonstrated in Fig. 2. Probability of wild boar visits was highest in Hofstetten (Hof: 0.39-0.40).

\section{Discussion}

The present study proves that the tested odor repellent was not effective in deterring wild boar from our luring sites. Although there is a wide range of studies on olfaction in wild boar and other suids, confirming the species' excellent

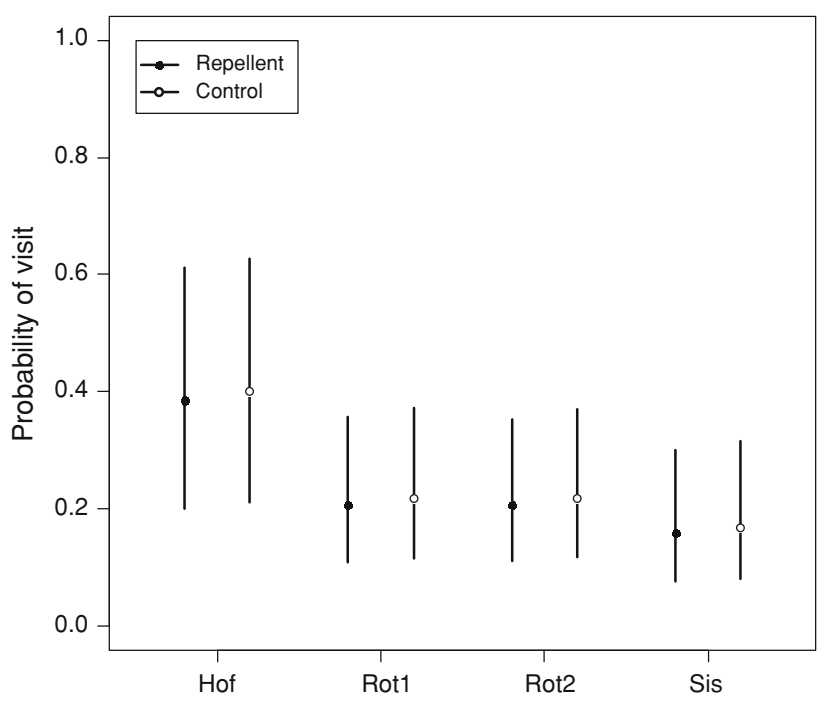

Fig. 2 Probability of wild boar visits at the study sites in Hofstetten (Hof), Rothenfluh (Rot1, Rot2), and Sissach (Sis). Predicted values (incl. 95\% CI) are applied for month $=11$ and duration $=200$

sense of smell (Zeuner 1967; Altevogt 1972; Meynhardt 1978; Günterschulze 1979; Briedermann 1990), scientific record on the effectiveness of odor repellents used for crop protection from wild boar damage is scarce.

Chemical repellents are widely used in wildlife damage management against a variety of species. In general, the effectiveness of chemical deterrents is conditionally confirmed in literature (Jordan and Richmond 1991; Milunas et al. 1994; El Hani and Conover 1995; Engeman et al. 1995; Belant et al. 1998; Mason 1998). However, there are big differences in efficacy between the repellents, depending on the species investigated, the population densities of target animals, and the functionality of the deterrent. Repellents causing pain are considered more effective, than those causing fear or sickness. The paincausing sensory irritants are most effective when being directly applied to crops. On the other hand, there is no evidence that targeted species abandon areas due to the effect of sensory irritants, because animals usually do not learn to avoid treated foods (Mason 1997).

The repellent investigated in the present study belongs to the wide range of fear-provoking products. In general, sulfur containing mixtures like "Wildschwein-Stopp ${ }^{\circledR}$ " are-to a certain degree-effective against herbivores. However, the effect of fear-inducing repellents bases on neophobia and target animals usually habituate to them very quickly (Mason 1997). Our results, however, do not confirm neophobia in the sense of an initial deterrence effect of the tested repellent, since the interaction treatment $\times$ duration did not have significant effect on wild boar visits at the luring sites. At one particular study site (Sis) wild boars surmounted the deterrent setup immediately in the night after installation. 
Our findings may indicate seasonal variation in wild boar activity outside forests. Maximum probability of visits at the luring sites is in spring and fall and coincides with the occurrence of damage to agricultural land. Several studies have revealed that wild boar damage to annual crops peaks in late summer and fall as a result of ripening of crops and fruit, which is in agreement with our results (Łabudzki and Wlazełko 1991; Geisser 2000; Herrero et al. 2006; Schley et al. 2008).

Previous studies evidenced that hunting effects wild boar behavior and activity range (Baubet et al. 1998; Sodeikat and Pohlmeyer 2002; Fernández-Llario et al. 2003). However, the interaction treatment $\times$ site did not significantly differ between the four study sites, which shows that site-specific factors such as remoteness, degree of anthropogenic impact, or wild boar density did not influence the effect of the odor repellent.

Since we neither found an overall- nor an initial effect of the tested odor repellent we conclude the repellent to be ineffective in deterring wild boars from agricultural fields. "Wildschwein-Stopp ${ }^{\circledR}$ " is therefore not recommendable for crop protection. Moreover, we suggest that any other odor repellent relying on fear-evocation would not be an effective deterrent against wild boar and feral swine, especially in areas where natural enemies like wolf (Canis lupus), brown bear (Ursus arctos), or lynx are absent or very rare.

Farmers of the Canton Basel-Land receive compensation for wildlife damage if their fields were adequately protected. To date only the electric fence has been proven to protect fields adequately from wild boar damage. On the basis of the present study, we suggest that compensation payment policies should not be changed for the present. We recommend that farmers should not be encouraged to use any deterrent systems other than electric fences to protect their fields.

However, more effort to develop new deterrent systems is needed since the problem of wild boar damage to agriculture is far from being solved. Without question, reduction and regulation of wild boar populations by means of hunting is crucial for preventing damage to agriculture. However, field protection will remain important and the need for inexpensive alternative deterrents will last since populations will recover within a short time also in the future.

Acknowledgments The present study was funded by the Volkswirtschafts- und Sanitätsdirektion of Basel-Land, the Federal Office for the Environment (FOEN), and the Freiwillige Akademische Gesellschaft (FAG). We thank I. Bloch and D. Zopfi, head and deputy of the department Veterinär-, Jagd- und Fischereiwesen for bringing us into contact with game wardens, hunters, and farmers at our study sites. A. Ochsenbein gave technical support and valuable input for the field experiments. C. Zentner and M. Küng, game wardens of Sissach and Rothenfluh, provided valuable information on the local conditions, activity ranges, and trails of the wild boars in the study area. We thank the farmers of Sissach, Rothenfluh, and Hofstetten for readily letting us perform our experiments on their land. F. Korner-Nievergelt calculated the logistic regression and the Bayesian model.

\section{References}

Altevogt R (1972) Zur Verhaltensökologie der Trüffelschweine des Perigords (AW-Frankreich). Wissenschaftliche Zeitschrift der Humboldt-Universität zu Berlin. Reihe Mathematik/Naturwissenschaften XXY 4:407-410

Andrzejewski R, Jezierski W (1978) Management of a wild boar population and its effect on commercial land. Acta Theriol 23:309-339

Baubet E, Brandt S, Touzeau C (1998) Effet de la chasse sur les stratégies d'occupation de l'espace des sangliers (Sus scrofa). Analyses préliminaires. Gib Faun Sauv 15:655-658

Belant JL, Seamans TW, Tyson LA (1998) Predator urines as chemical barriers to white-tailed deer. Proc 18th Vertebr Pest Conf 18:359-362

Bieber C, Ruf T (2005) Population dynamics in wild boar Sus scrofa: ecology, elasticity of growth rate and implications for the management of pulsed resource consumers. J Appl Ecol 42:1203-1213

Boisaubert B, Bouldoire JL, Vassant J (1983) Bilan de cinq années d'expérimentation de protection des cultures par clôtures électriques dans le département de la Haut-Marne. Bull Mens Off Natl Chasse 68:15-26

Breton D (1994) La limitation des dégâts de sanglier par la pose de clôtures électriques dans le département de la Haute-Marne. Bull Mens Off Natl Chasse 191 (Numéro special):96-100

Briedermann L (1990) Schwarzwild, 2nd edn. VFB Deutscher Landwirtschafts-Verlag, Berlin

Calenge C, Maillard D, Fournier P, Fouque C (2004) Efficiency of spreading maize in the garrigues to reduce wild boar (Sus scrofa) damage to Mediterranean vineyards. Eur J Wildl Res 50:112-120

Cellina S (2008) Effects of supplemental feeding on the body condition and reproductive state of wild boar Sus scrofa in Luxembourg. Dissertation, University of Sussex, Brighton

El Hani A, Conover MR (1995) Comparative analysis of deer repellents. Repellents in wildlife management conference proceedings, 8-10 Aug 1995, Denver, CO, USA, pp 147-155

Engeman RM, Campbell DL, Nolte D, Witmer G (1995) Some recent research results on non-lethal means for reducing animal damage to reforestation projects in the western United States. Proc 10th Aust Vertebr Pest Control Conf 10:150-154

Fernández-Llario P, Mateos-Quesada P, Silvério A, Santos P (2003) Habitat effects and shooting techniques on two wild boar (Sus scrofa) populations in Spain and Portugal. Z Jagdwiss 49: $120-129$

Geisser H (1998) The wild boar (Sus scrofa) in the Thurgau (northeastern Switzerland): population status, damages and the influence of supplementary feeding on damage frequency. Gib Faun Sauv Game Wildl 15((Special Number Pts 2 and 3)): $547-554$

Geisser H (2000) Das Wildschwein (Sus scrofa) im Kanton Thurgau (Schweiz): Analyse der Populationsdynamik, der Habitatansprüche und der Feldschäden in einem anthropogen beeinflussten Lebensraum. Dissertation, University of Zurich, Zurich

Geisser H, Reyer H-U (2004) Efficacy of hunting, feeding, and fencing to reduce crop damage by wild boars. J Wildl Manag 68:939-946 
Geisser H, Reyer H-U (2005) The influence of food and temperature on population density of wild boar Sus scrofa in the Thurgau (Switzerland). J Zool (Lond) 267:89-96

Günterschulze J (1979) Studien zur Kenntnis der Regio olfactoria von Wild-und Hausschwein. Zool Anz (Jena) 202(3/4):256-279

Hahn N, Eisfeld D (1998) Diet and habitat use of wild boar (Sus scrofa) in SW-Germany. Gib Faun Sauv 15:595-606

Herrero J, García-Serrano A, Couto S, Ortuño VM, García-González R (2006) Diet of wild boar Sus scrofa L. and crop damage in an intensive agroecosystem. Eur J Wildl Res 52:245-250

Jordan DM, Richmond ME (1991) Effectiveness of a vertical 3-wire electric fence modified with attractants or repellents as a deer exclosure. Proc East Wildl Damage Control Conf 5:44-47

Łabudzki L, Wlazełko M (1991) Saisonale Dynamik der vom Schwarzwild im Feldanbau verursachten Schäden im Forschungsgebiet Zielonka. Z Jagdwiss 37:250-257

Lutz W (1994) Ergebnisse der Anwendung eines sogenannten Duftzauns zur Vermeidung von Wildverlusten durch den Strassenverkehr nach Gehege-und Freilandorientierungen. Z Jagdwiss 40:91-108

Macdonald DW (2001) The new encyclopedia of mammals. Oxford University Press, Oxford

Mason JR (1997) Repellents. In: Wagner KK, Nolte DL (eds) Wildlife damage management for natural resource managers. Western Forestry and Conservation Association, Olympia, pp 11-16

Mason JR (1998) Mammal repellents: options and considerations for development. Proc Vertebr Pest Conf 18:325-329

Mazzoni della Stella R, Calovi F, Burrini L (1995) The wild boar management in a province of Central Italy. IBEX JME 3:188-191

Meynhardt H (1978) Schwarzwildreport. Neumann-Verlag, Leipzig (in German)

Meynhardt H (1991) Wildversorgung, Trophäen und Schadensverhütung. Schwarzwild-Bibliothek 4, Verlag Neumann-Neudamm, Melsungen (in German)

Milunas MC, Rhoads AF, Mason JR (1994) Effectiveness of odour repellents for protecting ornamental shrubs from browsing by white-tailed deer. Crop Prot 13:393-397
Schlageter A, Haag-Wackernagel D (2011) Effectiveness of solar blinkers as a means of crop protection from wild boar damage. Crop Prot 30:1216-1222

Schley L, Roper TJ (2003) Diet of wild boar Sus scrofa in Western Europe, with particular reference to consumption of agricultural crops. Mammal Rev 33:43-56

Schley L, Dufrêne M, Krier A, Frantz AC (2008) Patterns of crop damage by wild boar (Sus scrofa) in Luxembourg over a 10-year period. Eur J Wildl Res 54:589-599

Sodeikat G, Pohlmeyer K (2002) Temporary home range modifications of wild boar Sus scrofa caused by drive hunts in Lower Saxony (Germany). Z Jagdwiss 48(supplement 1):161-166

Spiegelhalter DJ, Thomas A, Best NG, Lunn D (2003) WinBUGS user manual (version 1.4). MRC Biostatistics Unit, Cambridge

Sturtz S, Ligges U, Gelman A (2005) R2WinBUGS: a package for running WinBUGS from R. J Stat Softw 12(3):1-16

Vassant J (1994a) Les techniques de prévention des dégâts de sanglier. Bull Mens Off Natl Chasse 191:90-93

Vassant J (1994b) L'agrainage dissuasif: résultats d'expériences. Bull Mens Off Natl Chasse 191:101-105

Vassant J (1997) Le sanglier en France: ces quinze dernières années. Bull Mens Off Natl Chasse 225:32-35

Vassant J, Boisaubert B (1984) Bilan des expérimentations enterprises en Haut-Marne pour réduire les dégâts de sanglier ( $\mathrm{Sus}$ scrofa) à l'encontre des cultures agrucoles. Smposium International sur le sanglier (international wild boar symposium). F. Spitz, and D. Pépin, technical coordinators. Toulouse, France, pp 187-199

Vassant J, Breton D (1986) Essai de reduction des dégâts de sangliers (Sus scrofa) sur blé (Triticum sativum) au stade laiteux par distribution de maïs (Zea mais) en forêt. Gib Faun Sauv 3:83-95

Vassant J, Jullien JM, Brandt S (1992) Reducing wild boar damage to wheat and oats in summer: study of the effectiveness of maize distribution in the forest. In: Bobek B, Perzanowski K, Regelin WL (eds) Proceedings of the 18th IUGB congress, global trends in wildlife management. Jagdellonian University, Krakow

Zeuner FE (1967) Geschichte der Haustiere. BLV-Verlag, München 